\title{
The military management in colleges and universities
}

\author{
Xianyu Meng ${ }^{*}$, Xiaoyan Cai, Lina Lu, Yu Ge, Jie Gao
}

Ordnance Non-commissioned Officer Academy of PLA, Wuhan, China

* Corresponding author: Xianyu Meng, master,849934279@qq.com

\begin{abstract}
Problems existed in management of college students under the popularization of higher education and traditional education has difficult to satisfy the educational management in colleges and universities, this paper discusses the militarization of management model in university management application.
\end{abstract}

Keywords: militarization; university; management

\section{Introduction}

Currently parts of the country after graduating from colleges and universities to ensure that students better adapted to the needs of the community, on the student management in military mode, students of military will, a correct life style and work style in order to improve students' comprehensive qualities. As more militarization management model in local universities, many colleges in using military means is there are a lot of problems, particularly militarization management mode of culture existing in current training goals of higher education and, therefore, local colleges and universities in the future military work to continuously improve the management model, Student unity of culture and education.

\section{The essence of the militarized management in colleges and universities}

College reference is the essence of the military forces closed management style, adopting strict regulations the student's way. Military academies to train high-quality personnel for the purpose of all closed military and consistent with " soul education " spirit train " on the discipline, skill, physical " Three specialist professional technical personnel of the new era ${ }^{1}$. By militarization management, develop students ' good habits, study habits, work habits, develop good personal image, students of high moral character, students ' sense of patriotism, patriotic, and exercises students a healthy body, cultivate team spirit. Comprehensive improvement of students ' comprehensive ability improve the quality of teaching in schools. 
So do military pursuit of strict discipline, and requiring students to do mob. Military is a serious and not rigid, lively and not chaotic management style.

\section{The main problems of the college students under the current management pattern in colleges and universities}

\subsection{The lack of honesty}

They Lack of honesty on the economic behavior of college students, but also in learning. Under the current management mode of University students in job plagiarism, cheating happens; false making curriculum vitae can be found everywhere. Missing credit to college students ' personal and social has brought a lot of damage. For individual students ' bad for our growth and development; for others, damage the interests of others, school, lower school education are affecting the quality of the image for society, increasing social instability.

\subsection{No sense of discipline and obedience}

In the era of unconventional, many students have false consciousness, lost and happy and up into the University reduce their demands. Students ignored discipline in schools, in violation of school management, repeated truancy, tardiness, behavior ${ }^{2}$.

\section{Military necessity}

First of all, not before entering University, students receive a lack of education on the cultivation of students ' autonomous learning ability, after many students enter college, appears in original mode of university education thought lax, get lazy, lack of active learning on the learning interest and motivation. Student management mode of opening education is in a position to complete the transition. Military can help students in colleges and universities in life and learning to develop good habits to help students complete their studies.

Secondly, the traditional mode of education management in colleges and universities, College teachers ' ideological, and teacher to student demand is not high, the declining quality of education. Militarization of management can be a very good outcome of University "into the wide" phenomenon. Military mode, teachers need to lead by example can have a positive impact on students, to guide students keeping in good study habits in life,Cultivating students qualities of discipline and hard work ${ }^{3}$.

Thirdly, improving the teaching quality in colleges and universities. After the expansion of enrollment in colleges and universities, this led to a surge in the number of style of study in 
colleges and universities and the drop in the quality of education. Higher education is no longer elite, but public education. Militarization management mode of college students under the guidance of school rules and regulations, strict with his students, contribute to the formation of excellent school spirit in colleges and universities and improving the quality of education.

\section{The militarization of management model in the existing problems}

After all, college are not exactly the same as the force, militarized management mode has its particularity, militarized management mode in colleges and universities, will have certain limitations, prone to various problems, problems if the University fails to timely solution, military work will go into error, the result can be counterproductive, Obstacles in the development.

\subsection{Student boredom}

Military mode, students living and studying in strict accordance with the system and too regular. Repeated mechanical movements over time and suffer from emotional boredom, psychologically rebellious, militarized management will achieve the opposite result.

\subsection{Rejection}

Military mode requires students to strict respect for authority, and militarization of management mode of a strong hierarchy, students must absolutely comply with an order to teachers and schools. Military mode of long-term passive subject position of students generates resistance and rejection. Wrong mental state can affect students ' interpersonal communication, not conducive to the formation of class cohesion, and contrary to the original intention of carrying out militarized management ${ }^{4}$.

\subsection{Inhibit students ' individual development}

Militarization of management mode suits for students of passive obedience, and innovation of students ' critical spirit suppressed, not conducive to the development of the individual student. In higher education, and all educational, student-oriented educational activities it is essential. Therefore, the single management under the military to some extent hindered the development of students. 


\section{Military development trend and problems}

On the implementation of the use of military, management of the Centre should not only stay in the system for the management and change management. Therefore, the University in charge of constantly need improve the management of, and unity. According to the school's management changes, constantly enrich the contents of military, military innovation change management practices, developing a cadre of military. At the time of change from system management to culture management, universities must fully understand some problems to do the militarization of development change management model [5].

\subsection{Cultural management: implementation of military unity of management and process}

Schools in achieving management objectives are to focus on training for cultural management environment and heritage, in the process of continuous improvement can best achieve its objectives. By system management, develop students ' self-discipline, culture management discipline, higher on request.

\subsection{Cultural management: management of system development}

Cultural management: systems development and management, is the advanced stage of development. Management phases of the military system, allow students to form a distinct culture and a high degree of autonomy. Management is not without cultural management system and still wants to continue to improve the system, system of role to play. Cultural management is managing system at all.

\subsection{Cultural management is a long-term process of change}

Universities want to change there is a clear awareness of the specific system management to the management of change is a permanent task. Transition needs continuous improvement of the system of required long-term accumulation in practice in colleges and universities and establish humanistic connotation of military, cultural connotation through long-term accumulation, to form a cultural management.

\subsection{School environment}

Harmonious campus environment are essential for achieving it, the right soil and atmosphere conducive to the formation and growth of the culture. Harmonious campus environment requires students and school leaders' work together to create, in coordination between various 
functions of the Department, together with the active participation of students and school leaders.

\section{Concluding remarks}

The educational needs of school management, militarized management model is used in schools is very important, but school is not a unit, management or education. Therefore, at the time of implementation of the military, should not only manage, that needs to be based on the military, integration of student's self-management, in order to better achieve the more stupid goals of education.

\section{References}

1. P. Ruan, Militarization of empirical research on the application of management in local colleges and universities [J]. Study of higher education ( Chengdu ), 2007, 01(2): 12-16.

2. P. Ruan, College future military options [J]. Modern preventive medicine, 2008, 01(03): 1-3.

3. L. Q. Yang, Under the popular education: paramilitary management of freshmen thought [J]. Theory and practice of education , 2005, 18(11): 21-23.

4. L. Q. Yang, Paramilitary management of freshmen in practice and reflection on College of Zhejiang Wanli University--also on the basis of paramilitary management [J]. Journal of Zhejiang Wanli University , 2005, 04(05): 141-143.

5. Y. С. Нua, cream . Problem analysis and reform thinking on management of colleges and universities [J]. Higher agricultural education , 20054 (4): 3-5. 